\title{
Tax Treatment of Employee Benefits
}

\author{
Yinhua $\mathrm{Pu}$ \\ Accounting Department \\ Southwest Jiaotong University of Hope College \\ Jintang, China
}

\author{
Chunyan Liu \\ Accounting Department \\ Southwest Jiaotong University of Hope College \\ Jintang, China \\ Yan Cheng \\ Accounting Department \\ Southwest Jiaotong University of Hope College \\ Jintang, China
}

\author{
Xiao Chen \\ Accounting Department \\ Southwest Jiaotong University of Hope College \\ Jintang, China \\ Jiasheng Wang \\ Accounting Department \\ Southwest Jiaotong University of Hope College \\ Jintang, China
}

\begin{abstract}
In present society, employee development has been the foundation of business development. The company has the obligation and responsibility to provide employees with basic benefits. Meanwhile, employees also have the obligation and responsibility to provide services for the enterprise. Thus, how to deal with these expenses will bring different tax burdens to enterprises and employees. For example, the expense for providing beverages for employees as labor security expenditures or employee benefits is different in tax burden.
\end{abstract}

\section{Keywords—new tax; employee benefits; tax planning}

\section{RELEVANT LAWS}

Relevant laws recognize the employee welfare fee including heating subsidy, staff heatstroke cooling fee, such as "Notice on Regulating the Issues Related to the Social Security Contribution Base" and the "Notice on Strengthening the Financial Management of Employee Benefits", and the "Notice of the State Administration of Taxation on the Issues of Enterprise Wages and Salaries and Staff Welfare Fees Deduction." However, according to the "Regulations for the Implementation of the Enterprise Income Tax Law of the People's Republic of China", reasonable wages and salary expenses incurred by enterprises shall be deducted. Employee welfare expenses incurred by enterprises shall be deducted but cannot exceed $14 \%$ of total wages and salaries. Meanwhile, the "Regulations on the Implementation of the Enterprise Income Tax Law of the People's Republic of China" stipulates that reasonable labor protection expenditures incurred by enterprises shall be deducted.

\section{ThOUghtS ON TAX PROCESSING OF EMPLOYEE WELFARE DISBURSEMENT}

According to the "Notice on Standardizing the Basis of Social Insurance Payments" and the "Regulations on the Implementation of the Enterprise Income Tax Law of the People's Republic of China", labor protection fees are not included in wages and employee welfare fees, but deducted directly as operating costs of enterprises before tax. Therefore, in the process of providing welfare for employees, enterprises should consider relevant laws and regulations. Considering from the perspective of enterprises and employees, it is beneficial for enterprises and employees to choose labor protection fee as expenditure according to law rather than employee welfare expenditure.

\section{CASE StUdy ON EMPlOyeE Welfare DISBURSEMENT IN ENTERPRISES}

In summer, whether the refreshing beverage provided by the enterprise as labor protection expenditure or employee welfare expenditure is closely related to the specific implementation of the enterprise. Different implementation would take different results for both enterprises and employees.

\section{A. Enterprises}

According to the implementation rules of enterprise income tax and the "Notice on Standardizing the Basis of Social Insurance Payments", if an enterprise treats beverage expenditure as labor protection, the purchase of labor protection products will not be included in the total amount of work but can be deducted before tax. If enterprise treats the fee as welfare expenses, it will be deducted according to 
recognized as the labor insurance expenditure rather than employee welfare expense. This program is more beneficial to employees.

For example, accounting profit of a construction enterprise in $20 * 9$ years is 1 million yuan, which is not included in the total cost of providing refreshing drinks for employees in the summer of that year. Assume that other taxes are not considered, of which the salary is 25 million yuan and the number of staff is 5,000. The employee welfare fee is 3.5 million yuan. Which is more advantageous for enterprises to include the 200,000 yuan in labor protection or as workers' welfare?

1) Option 1: The enterprise will use 200,000 yuan as labor protection, which can be deducted before tax. Then, the company's net profit $=100-20-(100-20) * 25 \%=60$

2) Option 2: The company will use 200,000 yuan as employee benefits. Therefore, this fee can be deducted by $14 \%$ of the salary. The actual welfare expenses of the enterprise are 3.5 million yuan, the deduction standard is $2500 * 25 \%=3.5$ million yuan, and the 200,000 yuan exceeds the deduction standard, and pre-tax deduction is not allowed. Then, the company's net profit is: $100-100 * 25 \%$ $20=550,000$ yuan

For companies, profitability is fundamental to their survival. According to the above two calculations, it is more advantageous to use the fee as labor security. Therefore, companies should choose option one.

\section{B. Employees}

1) Option 1: Labor protection is a necessary condition for enterprises to provide employees with a safe and good working environment. It is also a special protection measure for workers working in high temperature in summer. In the above case, the company purchased the beverage for 200,000 yuan as labor protection. These fees can be included in the relevant cost rather than salary and welfare. Therefore, salary and welfare of employees will not be affected and will not increase their personal income. It will not increase the personal income tax of employees. The personal wage is 5000 yuan, and the ultimate personal income is 5000 yuan.

2) Option 2: As employee welfare expenses, the personal income tax will be increased, thereby reducing the personal income of employees. Assuming no other benefits are considered. The staff salary is 5,000 yuan. In this case, the company pays 200,000 yuan to buy drinks. Thus, company pays 40 on average to each person. In accordance with tax laws, these fees should be incorporated into individual wages and paid personal income tax. According to the latest personal work salary scale, individuals should:

personal income tax $=(5040-5000) * 3 \%-0=1.2$ yuan

The income from the staff after the tax is:

$$
5000-1.2=4998.8 \text { yuan }
$$

Therefore, for the individual employee, the beverage purchased by the company in the summer should be

\section{Specific Practices of Enterprises}

As early as 2012, in order to strengthen the labor protection work of high-temperature operation and hightemperature weather operations, and safeguard the health of workers and their related rights and interests. The State Administration of Safety Supervision, the Ministry of Health, the Ministry of Human Resources and Social Security revised the "Interim Measures for Heat Prevention and Cooling Measures" and formulated the Measures for the Management of Heat Prevention and Cooling Measures.

In this method, it is clearly stipulated that the company should provide sufficient $\mathrm{d}$ cooling beverages and essential medicines for workers working in high temperature. It is not allowed to replace cooling beverages with money. Cooling drinks are not allowed to cover the allowance for high temperature.

In view of the tax law and the financial standards of enterprises, the relevant provisions on the welfare of employees given by high temperature in summer are more beneficial to enterprises and workers as labor protection or workers' welfare. According to relevant laws and regulations, enterprises do not pay employees directly for the cost of heat prevention and cooling in summer. This part of the cost should be directly used for the purchase of refreshing drinks. However, it is important to establish the relevant system of labor protection and treat expenditures of this kind as labor protection expenditures. Thus, it can reduce the tax burden of enterprises and employees and increase their income.

\section{CONCLUSION}

In the market economy, the fundamentals of enterprise survival are creating profit. How to get the maximum profit is the primary task. Minimizing corporate tax costs means higher taxes after taxes. According to the relevant tax laws and regulations, selecting the expenses incurred by creating the safety and good environment as expenditure of labor protection is more beneficial from the perspectives of both the enterprise and employees.

\section{REFERENCES}

[1] Wu Meihua. Personal income tax planning of employees and its impact on enterprises under the reform of personal tax. Beijing, 2019, pp.157-158.

[2] Ju Yunxia. Discussion on the problems and Countermeasures after the reform of the new individual income tax, shanghai, 2019, pp. 154.

[3] Cheng Yan, Wen Yan. Can employees change into outsourcers in the new era of personal income tax, Chengdu, 2019, pp., 49-52.

[4] Peng Jinqing, Xiao Yinfei. A study on the impact of the reform of individual income tax special deduction on the consumption intention of households based on the analysis of survey data before the implementation of tax reform. Beijing, 2019, pp.62-6. 